\title{
PERANAN AUDIT-PENGOLAHAN DATA ELEKTRONIK SEBAGAI ALAT UNTUK MENINGKATKAN EFEKTIFITAS PENGOLAHAN GAJI DAN UPAH
}

\author{
Dedy Suryadi \\ Program Studi Komputerisasi Akuntansi Politeknik TEDC Bandung \\ Jl. Pasantren Km. 2 Cibabat - Kota Cimahi \\ Email : dsuryadi@poltektedc.ac.id
}

\begin{abstract}
Abstrak
Dengan adanya perkembangan teknologi komputeryang semakin maju, semakin banyak perusahaan yang menggunakan jasa komputer untuk memproses data akuntansi dan komputer merupakan alat bantu yang sangat bermanfaat dalam sistem informasi akuntansi. Selain adanya pergeseran pemanfaatan sumber daya, dengan penggunaan sistem pengolahan data elektronik akan timbul berbagai karateristik yang baru, karakteristik yang baru tersebut salah satu diantaranya adalah kekonsistenan. Dengan adanya kekonsistenan, penggunaan sistem pengolahan data elektronik bukan berarti menjadi bebas resiko tetapi sifat kekonsistenan ini dapat menjadi resiko baru dalam pengolahan data menjadi informasi. Penelitian ini bertujuan untuk mengetahui efektifitas untuk meningkatkan pengolahan gaji dan upah. Metode penelitian yang digunakan metode deskrptif yaitu dengan cara menguraikan, mengumpulkan, mengolah dan menganalisis data. Hasil penelitian menunjukkan bahwa dengan menggunakan sistem pengolahan data elektronik segala informasi yang dibutuhkan dapat diperoleh secara cepat, tepat dan lengkap sehingga dapat meningkatkan efektifitas pengolahan gaji dan upah.
\end{abstract}

Kata kunci: audit, PDE, efektifitas, gaji dan upah

\begin{abstract}
With the development of technology komputeryang more advanced, more and more companies are using the services of a computer to process accounting data and the computer is a tool that is very useful in accounting information systems. In addition to the shift in resource utilization, with the use of electronic data processing systems will arise various new characteristics, the characteristics of the new one of them is consistency. With the consistency, the use of electronic data processing system does not mean being a risk-free but the nature of this consistency can be a risk in processing the data into information. This study aims to determine the effectiveness to improve the processing of salaries and wages. The research method used descriptive method that is by outlining, collect, process and analyze data. The results showed that by using an electronic data processing systems all the required information can be obtained quickly, accurately and completely so as to increase the effectiveness of the processing of salaries and wages.
\end{abstract}

Keywords: audit, PDE, effectiveness, salaries and wages

\section{PENDAHULUAN}

Kegiatan pembangunan dewasa ini semakin meningkat dengan terus berkembangnya teknologi yang semakin luas dan komplek. Untuk itu diperlukan pengembangan sumber daya manusia yang tidak dapat dipisahkan dari langkahlangkah pengembangan industri. Perkembangan yang terjadi pada teknologi informasi akhir-akhir ini memungkinkan untuk mendapatkan informasi secara efisien dan efektif.

Komputer sebagai alat dan sistem pengolahan data secara elektronik mempunyai peranan yang penting untuk membantu manajemen dalam memecahkan berbagai problema yang dihadapinya. Bagi seorang manajer dalam perusahaan-perusahaan yang besar mempunyai tanggungjawab yang paling menentukan sukses tidaknya perusahaan yang dipimpinnya.

Dengan adanya perkembangan teknologi komputer yang semakin maju, semakin banyak perusahaan yang menggunakan jasa komputer untuk memproses data akuntansi dan komputer merupakan alat bantu yang sangat bermanfaat dalam sistem informasi akuntansi. Selain adanya pergeseran pemanfaatan sumber daya, dengan penggunaan sistem pengolahan data elektronik akan timbul berbagai karakteristik baru. Karakteristik yang baru tersebut salah satu diantaranya adalah kekonsistenan.

Dengan adanya karakteristik dan risiko baru akibat penggunaan sistem pengolahan data elektronik, maka dibutuhkan adanya pengendalian yang berbeda daripada penggunaan sistem manual. Audit pengolahan data elektronik akan menguji sistem sistem pengendalian intern yaitu untuk menentukan apakah sistem komputer tersebut melindungi harta perusahaan, menjaga keutuhan data, mencapai tujuan organisasi secara efektif dan menggunakan sumber-sumber secara efisien.

Audit pengolahan data elektronik atas gaji dan upah karena terdiri dari beberapa unsur seperti gaji pokok, premi, lembur, uang makan dan lain-lain serta merupakan faktor biaya dalam perusahaan yang harus terus menerus dikeluarkan 
selama perusahaan itu berjalan. Pengawasan terhadap gaji dan upah terasa tidak efektif jika dilakukan dengan cara konvensional atau manual, karena data harus dicatat atau diproses berulang kali dalam upaya menyusun laporan, dengan harus dicatatnya berulang kali suatu laporan atau informasi yang dibutuhkan menjadi terlambat disajikan, maka dengan menggunakan sistem pengolahan data elektronik segala informasi yang dibutuhkan dapat diperoleh secara cepat, tepat, dan lengkap tanpa harus melakukan proses pencatatan yang berulang-ulang

\section{TINJAUAN LITERATUR}

\section{Konsep Pengolahan Data Elektronik (PDE)}

Untuk dapat menghasilkan informasi yang sesuai dan dalam bentuk yang sesuai juga, diperlukan suatu sistem yang mengatur arus pengolahan data akuntansi dalam perusahaan, yang secara garis besar dapat digambarkan sebagai berikut :

\begin{tabular}{|l|l|l|}
\multicolumn{1}{c|}{ DATA } \\
Fakta-fakta tak \\
terstruktur
\end{tabular}$\rightarrow$\begin{tabular}{|l|l|} 
SISTEM \\
$\begin{array}{l}\text { Sekumpulan } \\
\text { hubungan- } \\
\text { hubungan dan } \\
\text { prosedur } \\
\text { pengolahan } \\
\text { yang } \\
\text { terorganisasi }\end{array}$ \\
INFORMASI \\
$\begin{array}{l}\text { Data terpilih } \\
\text { diorganisasi, } \\
\text { dikumpulkan } \\
\text { dimanipulasi } \\
\text { menjadi baru } \\
\text { dan berarti }\end{array}$ \\
\hline
\end{tabular}

Gambar 1. Pengolahan data menjadi informasi

Data merupakan fakta-fakta yang mengandung arti tetapi belum terstruktur, seperti definisi yang dikemukakan oleh Barry E. Cushing (10, hal. 9): "Data can be thought of as comprising any set of characters wich is accepted as input to an information system

Sedangkan informasi merupakan keluaran dari suatu proses pengolahan data, seperti definisi yang dikemukakan and is stored and processed."

oleh Barry E. Cushing (10, hal. 9) : "Information refor to an output of data processing which is organized and meaningful to the person wo receives it."

Dalam sistem informasi akuntansi proses pengolahan dilakukan dengan beberapa tahap, terlihat proses pengolahan data dapat dilakukan dalam siklus akuntansi baik secara manual dan secara komputer, seperti dalam gambar berikut :

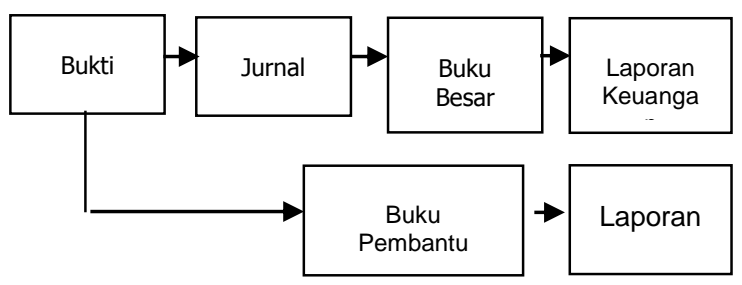

Gambar 2. Pengolahan data menjadi informasi

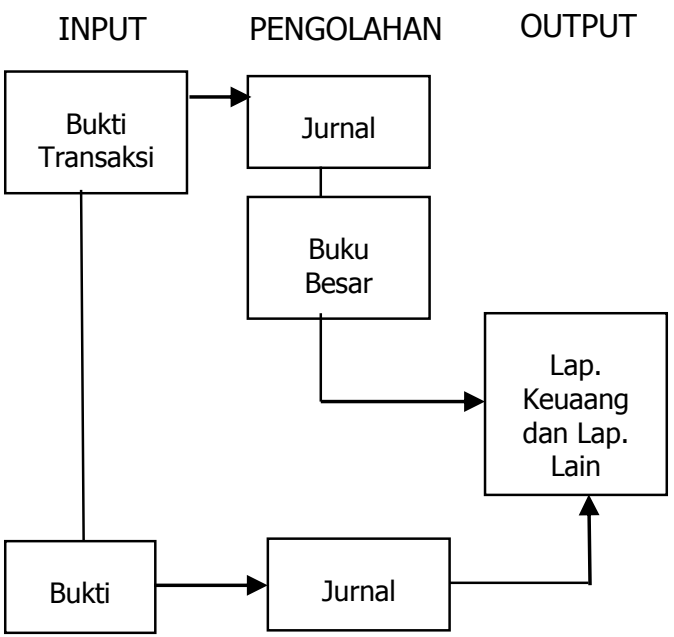

Gambar 3. Siklus pengolahan data secara manual dan dengan komputer

Istilah pengolahan data elektronik (PDE) dapat didefinisikan menurut pendapat J.M. Van Dorschot (8, hal. 36) : "Electronik Data ....is a term used for describing the processing of data largelly by electronic means in a computer plays the key role."

\section{Audit - Pengolahan Data Elektronik (Audit- PDE) \\ Pengertian Audit-PDE bukanlah} merupakan pemeriksaan yang dilakukan oleh AkuntanPublik terhadap klien, akan tetapi merupakan suatu tahapan khusus internal audit yang ada di perusahaan yang menggunakan PDE. Menurut H.S Hadibroto dalam majala bulanan Akuntan vol 1 no. 4 tahun 1980, mengemukakan pendapatnya sebagai berikut : "Penggunaan komputer merupakan susunan sistem pengawasan intern, sehingga terdiri dari 3 sub-sistem yaitu :1) sistem pengawasan akuntansi; 2) sistem pengawasan administrative; 3) sistem pengawasan komputer." Skema sistem pengawasan

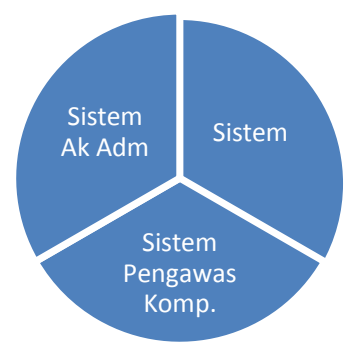

Gambar 4. Skema sistem pengawasan internal

Untuk memperjelas pengertian Audit PDE pada Glossary Data Processing Audit Practice Report, IBM Grant to Institue Internal Auditors (IIA) Altamonte Spring Florida $(1977 ; 129)$ yang dikutipoleh W. Hari Purnomo menjelaskan 
pengertian Audit - PDE sebagai berikut : "EDP Audit a specialized phase of internal audit that pertaints to the review, evaluation, and verification of control governing data processing and the result of data processing, such as data.... files and report."

Dari definisi tersebut di atas dapat ditarik kesimpulan mengenai Audit - PDE, yaitu :

1. Merupakan suatu tahapan khusus dari internal auditing secara keseluruhan

2. Ruang lingkupnya meliputi review, evaluasi dan verifikasi dari pengendalian-pengendalian yang berlaku atau sudah ada pada PDE tersebut

3. Hal-hal yang diperoleh dari pemrosesan data tersebut yang berarti berkaitan dengan data input, pemrosesan maupun outputnya.

Berikut di bawah ini adalah proses Audit - PDE sebagai berikut :

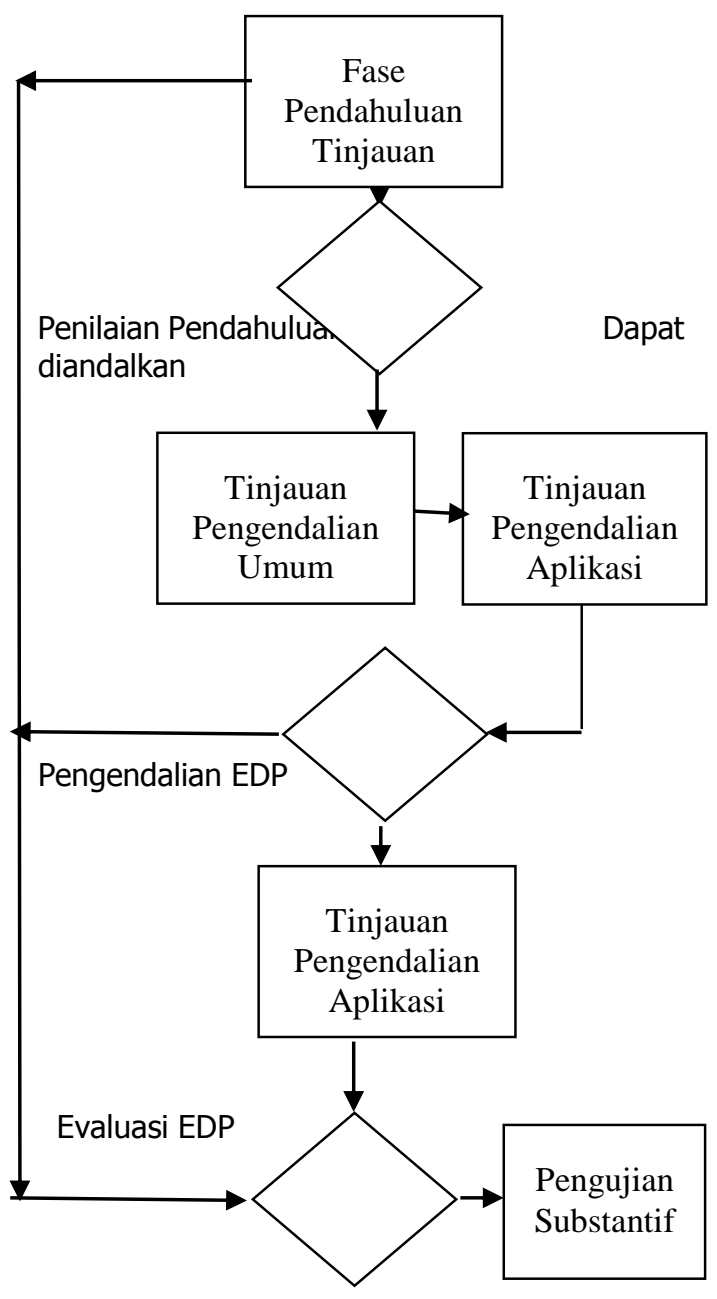

Gambar 4. Proses Audit - EDP

\section{Sistem Pengendalian Intern}

Biasanya manajemen dalam menjalankan tugasnya adalah melihat, meneliti, menganalisa dan mengambil keputusan atas laporan-laporan dari departemen atau bagian yang berada dibawahnya yang telah sampai di meja manajemen, dengan laporan juga manajemen dapat menilai apakah kebijaksanaan perusahaan yang telah ditentukan dijalankan dengan baik atau tidak, apakah kondisi finansial perusahaan sehat, apakaj semua kegiatan sudah berjalan sesuai dengan prosedur yang ditetapkan. Dengan kenyataan yang demikian ini telah mendorong manajemen untuk berusaha menciptakan atau menyusun sistem pengendalian intern yang baik.

Lebih lanjut AICPA (American Institute of

Certified Public Accountants) memberikan definisi sebagai berikut : "Sistem pengendalian intern meliputi struktur organisasi, semua metode dan ketentuan-ketentuan yang terkoordinasi yang dianut dalam perusahaan untuk melindungi harta kekayaan, memeriksa ketelitian, dan seberapa jauh data akuntansi dapat dipercaya, meningkatkan efisiensi usaha dan mendorong ditaatinya kebijakan perusahaan yang telah ditetapkan."

Adapun jenis pengendalian dalam hal ini ada 2 (dua) yaitu pengendalian umum dan pengendalian aplikasi, seperti dalam tabel dibawah ini :

Tabel 1. Jenis Pengendalian

\begin{tabular}{|l|ll|}
\hline \multicolumn{1}{|c|}{$\begin{array}{c}\text { Kategori } \\
\text { Pengendalian }\end{array}$} & \multicolumn{2}{|c|}{$\begin{array}{l}\text { Jenis - Jenis } \\
\text { Pengendalian }\end{array}$} \\
\hline Pengendlian Umum & 1. & $\begin{array}{l}\text { Organisasi dan } \\
\text { manajemen }\end{array}$ \\
& 2. & Piranti lunak \\
3. & $\begin{array}{l}\text { Pengendalian } \\
\text { akses }\end{array}$ \\
& 4. & $\begin{array}{l}\text { Data } \\
\text { prosedur dan }\end{array}$ \\
& 5. & $\begin{array}{l}\text { Pengembangan } \\
\text { sistem baru }\end{array}$ \\
& 6. & $\begin{array}{l}\text { Pemeliharaan } \\
\text { program } \\
\text { Dokumentasi }\end{array}$ \\
\hline Pengendalian & 7. & $\begin{array}{l}\text { Pengendalian } \\
\text { masukan }\end{array}$ \\
Aplikasi & 2. & $\begin{array}{l}\text { Pengendalian } \\
\text { pengolahan } \\
\end{array}$ \\
& 3. & $\begin{array}{l}\text { Pengendalian } \\
\text { keluaran }\end{array}$ \\
\hline
\end{tabular}

\section{Pengendalian Pengolahan Gaji dan Upah}

Ada beberapa pengertian gaji dan upah yang berbeda dari beberapa ahli, menurut Mulyadi mengemukakan tentang gaji dan upah sebagai berikut : "Gaji umumnya pembayaran atas penyerahan jasa yang dilakukan oleh karyawan yang mempunyai jenjang jabatan, sedangkan upah umumnya merupakan pembayaran jasa atas penyerahan jasa yang dilakukan oleh karyawan pelaksana. Umumnya gaji dibayarkan secara tepat per bulan, sedangkan upah dibayarkan 
berdasarkan hari kerja, jam kerja atau jumlah satuan produk yang dihasilkan oleh karyawan." Adapun unit organisasi yang terlibat dalam kegiatan gaji dan upah adalah :

1) Bagian kepegawaian

2) Bagian pencatat waktu

3) Bagian gaji dan upah

4) Bagian utang

5) Bagian kasir

6) Bagian kartu persediaan dan kartu biaya

7) Bagian jurna, buku besar dan laporan Dalam sistem dan prosedur akuntansi gaji dan upah terdiri dari :

1) Sistem dan prosedur penempatan karyawan (employment procedure)

2) Sistem dan prosedur pencatatan waktu (time keeping procedure)

3) Sistem dan prosedur penggajian dan pengupahan.

\section{Pengertian Efektivitas}

Pengertian yang paling mudah bahwa efektifitas dipandang dari sudut pencapaian tujuan optimum, seperti yang diungkapkan Richard $M$. Steers mengenai efektifitas sebagai berikut : "Efektifitas organisasi dapat dipandang sebagai batas kemampuan organisasi mendapatkan dan memanfaatkan sumber daya yang tersedia untuk mencapai tujuan operatif dan operasionalnya."

Berikut ini pengertian efektifitas organisasi oleh JB. Heckert sebagai berikut : "Suatu organisasi yang efektif dapat didefinisikan sebagai suatu kelompok individu yang bekerja sama mengambil tindakan-tindakan yang dapat mencapai suatu tujuan."Jadi efektifitas adalah hubungan antara masukan dan tujuan yang hendak dicapai, jadi sejauhmana organisasi berhasil mendapatkan dan memanfaatkan sumber daya dalam usahanya mengejar tujuan operasi dan tujuan operasionalnya.

\section{METODOLOGI}

Adapun metodologi penelitian yang digunakan, yaitu dengan analisis deskriptif kualitatif untuk mengetahui peranan audit pengolahan data elektronik sebagai alat untuk meningkatkan efektifitas pengolahan gaji dan upah berdasarkan teori. Lalu peneliti mengevaluasi tersebut berdasarkan beberapa sampel yang diambil berkaitan dengan pengolahan gaji dan upah kemudian menggunakan Internal Control Questionaires untuk mengetahui sistem pengendalian intern yang berjalan sudah efektif.

\section{Jenis Penelitian}

Ditinjau dari jenis masalah yang akan diteliti, data yang diperlukan, teknik pengumpulan data dan alat analisis yang akan digunakan, maka jenis penelitian yang akan diteliti adalah penelitian deskriptif.

\section{Data yang diperlukan}

Adapun data yang diperlukan dalam penelitian ini meliputi data primer dan sekunder, baik bersifat kualitatif maupun kuantitatif.

\section{Teknik Pengumpulan Data}

Setelah disesuaikan dengan metode penelitian yang dipilih, maka teknik pengumpulan data yang digunakan meliputi:

1) Observasi, yaitu teknik pengumpulan data yang dilakukan dengan pengamatan secara langsung terhadap aktivitas perusahaan yang erat kaitannya dengan penerapan audit - PDE dalam pengolahan gaji dan upah.

2) Wawancara, yaitu teknik pengumpulan data dengan cara tanya jawab langsung dengan pejabat yang berwenang yang ada kaitannya dengan objek penelitian. Dari hasil wawancara, penulis akan memperoleh data mengenai gambaran umum dan sejarah perkembangan perusahaan, struktur organisasi, uraian tugas dan wewenang, kebijakan dan prosedur, serta manfaat sistem pengendalian intern audit - PDE yang menunjang didalam perusahaan khususnya dalam meningkatkan efektifias pengolahan gaji dan upah.

3) Kuesioner, yaitu suatu teknik pengumpulan data dengan mengajukan daftar pertanyaan yang diisi oleh pejabat yang bersangkutan, untuk mendapatkan data mengenai masalah yang diteliti yaitu sejauh manakah manfaat audit - PDE yang diterapkan perusahaan dapat meningkatkan efektivitas pengolahan gaji dan upah.

\section{Alat Analisis}

Untuk mengetahui peranan audit - PDE, maka metode yang digunakan adalah analisis deskriptif kualitatif, maksudnya adalah untuk melihat dan menjelaskan sistem pengendalian intern pengolahan gaji dan upah, kemudian dibandingkan dengan teori yang mendukung penelitian ini.

Untuk mengevaluasi peranan audit - PDE dalam meningkatkan efektifitas pengolahan gaji dan upah, juga menggunakan analisis deskriptif kualitatif, yaitu menganalisa data berdasarkan informasi-informasi yang diperoleh dan didukung oleh pendapat responden dari pertanyaan yang diberikan melalui kuesioner.

Selain membandingkan dengan beberapa sampel yang ditetapkan dengan aktualisasinya. Untuk mengevaluasiperanan audit - PDE dalam meningkatkan efektivitas pengolhan gaji dan upah dan menggunakan pendekatan yang umum dilakukan dalam evaluasi kebijakan sistem pengendalian intern pengolahan gaji dan upah. 


\section{HASIL DAN PEMBAHASAN}

\section{Pelaksanaan Audit-PDE Atas Pengolahan Gaji dan Upah}

Dapat dikatakan sejak berdirinya Perusahaan sudah dibentuk aparat pengawasan, ini menunjukkan bahwa top manajemen sangat memperhatikan dan memerlukan pengawasan fungsional. Perkembangan SPI di Perusahaan dapat digambarkan sebagai berikut

Tabel 2. Perkembangan Pengawasan (SPI)

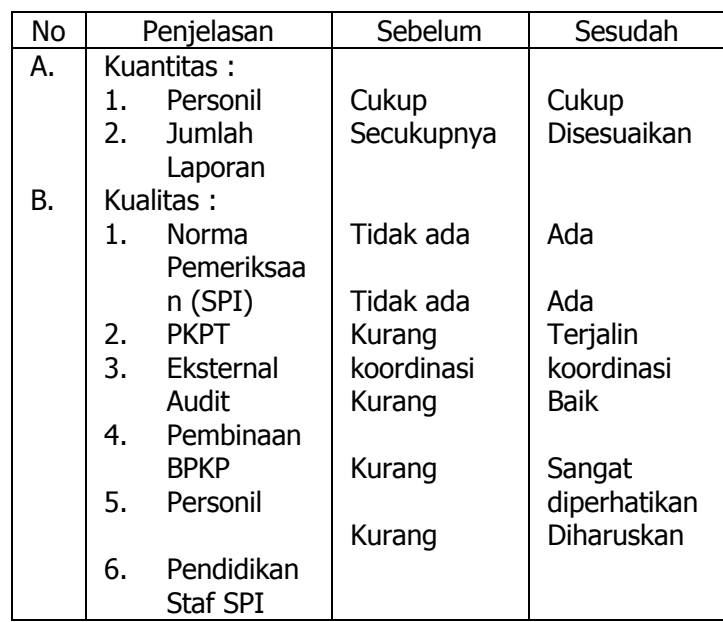

\section{Pelaksanaan Audit-PDE atas Pengolahan Gaji dan Upah}

Dalam melaksanakan pemeriksaan perlu adanya organisasi pemeriksa sehingga semua wewenang dan tanggung jawabtelah diatur sedemikian rupa sehingga setiap personil dapat mengetahui dengan jelas wewenang dan tanggung jawabnya. Pelaksanaan pemeriksaan perlu adanya langkah-langkah pemeriksaan seperti :

a. Adanya perencanaan pemeriksaan

b. Adanya ruang lingkup pemeriksaan

c. Adanya pelaksanaan pemeriksaan

d. Adanya hasil/laporan pemeriksaan

e. Adanya tindak lanjut

Berdasarkan uraian diatas dapat disimpulkan bahwa organisasi pemeriksa pada SPI Perusahaan telah memadai karenanya dapat menunjang berperannya Audit PDE.

\section{Pelaksanaan Pengendalian Intern atas Pengolahan Gaji dan Upah}

Pengendalian intern pada pengolahan data elektronik dibagi menjadi 2 (dua) bagian yaitu :

1) Pengendalian umum, bertujuan untuk membuat rerangka pengendalian menyeluruh atas aktivitas PDE dan untuk memberikan keyakinan memadai bahwa tujuan pengendalian intern secara keseluruhan dapat tercapai.

2) Pengendalian aplikasi, bertujuan untuk menetapkan prosedur pengendalian khusus atas aplikasi akuntansi untuk memberikan keyakinan memadai bahwa semua transaksi telah diotorisasi dan dicatat serta diolah seluruhnya dengan cermat dan tepat waktu.

Berdasarkan uraian diatas dapat disimpulkan bahwa dalam pengendalian intern pengolahan data elektronik terbagi menjadi dua yaitu pengendalian umum dan pengendalian aplikasi telah dilaksanakan dengan baik dan memadai sehingga dapat menunjang berperannya audit PDE serta pelaksanaan aktivitas pengolahan gaji dan upah>

\section{Pembahasan Pengendalian Pengolahan Gaji dan Upah}

Pengolahan gaji dan upah adanya bagianbagian yang terlibat dalam pengolahan gaji dan upah tersebut. Bagian-bagian yang terlibat adalah sebagai berikut :

a. Biro kepegawaian

b. Biro komputer

c. Biro keuangan

d. Biro akuntansi

Didalam pengolahan gaji dan upah juga perlu adanya pemisahan fungsi terhadap beberapa bagian yang terlibat seperti fungsi pencatatan, fungsi pengolahan, fungsi pembuatan daftar gaji, fungsi pembayaran dan fungsi pembukuan.

Prosedur dalam pengolahan gaji dan upah adalah sebagai berikut :

a. Prosedur penerimaan dan penempatan karyawan

b. Prosedur pencatatan kehadiran

c. Prosedur pembuatan daftar gaji

d. Prosedur pembayaran gaji

Dan hal yang sangat diperlukan adalah pencatatan dan pelaporan, dimana pencatatan memegang pengaruh penting bagi penyusunan laporan keuangan dan pembayaran kas secara actual sehingga perlu ditangani dengan hati-hati begitu pula terhadap dokumen dan bukti-bukti pendukungnya yang digunakan dalam pengolahan gaji dan upah.

Selain itu sistem pealporan intern tetap diperlukan dalam tiap organisasi, yaitu guna menyajikan informasi actual tentang perkembangan peristiwa, kemajuan dan prestasi organisasi.

Berdasarkan uraian diatas dapat disimpulkan bahwa pada Perusahaan dalam pengolahan gaji dan upah telah berjalan cukup baik dan memadai, karena :

1) Adanya struktur organisasi yang jelas dan tegas sehingga semua wewenang dan tanggung jawab telah diatur sedemikian rupa sehingga setiap karyawan dapat mengetahui dengan jelas wewenang dan tanggung jawabnya.

2) Adanya pemisahan fungsi terhadap beberapa bagian yang terlibat dalam pengolahan gaji dan 
upah.

3) Adanya prosedur-prosedur yang memadai yang digunakan dan diciptakan secara efektif dan efisien.

4) Adanya penggunaan formulir, catatan dan dokumen-dokumen penting lainnya dalam pengolahan gaji dan upah.

\section{Pembahasan Efektifitas Pengolahan Gaji dan Upah}

Efektifitas dalam pengolahan gaji dan upah adalah hubungan antara prosedur audit PDE dalam sistem informasi akuntansi gaji dan upah, dengan terciptanya efektifitas pengolahan gaji dan upah yang terkendali mendukung terciptanya peningkatan efektifitas pengolahan gaji dan upah.

Pelaksanaan audit PDE pada sistem pengendalian intern dapat berperan dengan baik dan memadai yang didukung oleh adanya faktorfaktor pendukung seperti organisasi pemeriksa, perencanaan dan pelaksanaan pemeriksaan serta tindak lanjut dari hasil pemeriksaan. Hasil tersebut juga didukung oleh adanya pengendalian umum dan pengendalian aplikasi yang menunjang berperanya audit PDE sehingga terciptanya pengendalian atas pengolahan gaji dan upah, dengan demikian pelaksanaan aktivitas pengolahan gaji dan upah sesuai dengan peraturan pemerintah maupun kebijakan intern perusahaan, serta tidak menyimpang dari perencanaan aktivitas dan penentuan tujuan yang ingin dicapai.

Dengan terciptanya pelaksanaan aktivitas pengolahan gaji dan upah yang terkendali mendukung terciptanya peningkatan efektifitas pengolahan gaji dan upah.

\section{Peranan Audit-PDE sebagai Alat untuk Meningkatkan Efektifitas Pengolahan Gaji dan Upah}

Dari hasil pembahasan tersebut diatas maka peran audit PDE yang dapat meningkatkan efektifitas dalam pengolahan gaji dan upah dapat disimpulkan secara keseluruhan sebagai berikut :

1. Struktur organisasi dan pemisahan fungsi sudah dilakukan dengan baik.

2. Program pemeriksaan intern sudah dilakukan dengan baik.

3. Prosedur-prosedur dan pelaksanaan otorisasi sudah dilakukan dengan baik.

4. Penggunaan dokumen dan catatan sudah dilakukan dengan baik.

5. Pengendalian umum dan pengendalian aplikasi pada perusahaan sudah dilakukan dengan baik.

Maka pelaksanaan audit PDE dalam sistem informasi akuntansi gaji dan upah yang diterapkan perusahaan terhadap pengendalian intern gaji dan upah dapat memenui kriteriakriteria yang telah ditetapkan perusahaan.

\section{KESIMPULAN DAN SARAN}

\section{Kesimpulan}

Berperannya audit PDE dengan baik dan memadai yang didukung oleh adanya faktor-faktor pendukung seperti organisasi pemeriksaan, ruang lingkup, program pemeriksaan, serta tindak lanjut dan didukung oleh adanya pengendalian umum dan pengendalian aplikasi, maka hal tersebut dapat mendukung terciptanya pelaksanaan aktivitas pengolahan gaji dan upah yang terkendali dan mendukung terciptanya peningkatan efektifitas pengolahan gaji dan upah.

a. Adanya struktur organisasi setiap personil dapat mengetahui dengan jelas wewenang dan tanggung jawabnya.

b. Adanya prosedur pemeriksaan terhadap pengolahan gaji dan upah yang digunakan oleh perusahaan sangat menunjang terwujudnya suatu pelaksanaan pemeriksaan yang berhasil artinya pemeriksaan yang dilaksanakan dapat lebih efektif dan efisien.

c. Pengendalian umum dan pengendalian aplikasi dapat menunjang dalam berperannya audit PDE serta pelaksanaan aktivitas pengolahan gaji dan upah

d. Pengendalian pengolahan gaji dan upah sudah berjalan dengan baik karena didukung oleh faktor-faktor yang ada dalam sistem pengendalian intern.

\section{Saran}

1) Perlu dibuatnya bagan alir atau flowchart yang berkaitan dengan masalah pengolahan gaji dan upah sehingga akan mendukung pada prosedur pengolahan gaji dan upah.

2) Bagan arus yang ada tersebut sebaiknya lebih diperjelas dengan memberikan keterangan serta dokumen-dokumen yang mendukung pada prosedur tersebut.

3) Sistem pengendalian intern yang sudah ada hendaknya dapat dijadikan sebagai awal dari langkah-langkah dalam pengambilan keputusan untuk mendapatkan hasil yang lebih baik dari keadaan sekarang.

\section{Daftar Pustaka}

Arens, A. Alvin dan Loebbecke, James K, "Auditing Suatu Pendekatan Terpadu", Erlangga.

Arens, A. Alvin dan Loebbecke, James K, "Auditing an Intregrated Approach", Englewood Cliffs, New Jersey:Prentice Hall, Inc., 1988.

American Institute of Certified Public Accountants, "Statememnt on Auditing Standard No. 48", New York, 1982.

Baridwan Zaki, "Sistem Informasi Akuntansi", BPFE, Edisi, Yogyakarta.

Cushing, Barry E, "Sistem Informasi Akuntansi dan Organisasi Perusahaan", Erlangga, Edisi, Jakarta.

Cusing, Barry E., "Accounting Information System 
and Business Organization" Third Edition, Addison Wesley Publishing Company, Massachussetts, 1982.

Gore R Marvin and Stubbe W., John, "Computer and Data Processing", New York, McGraw ill, Inc, 1979.

Hanson J.L., "Addictionary of Economic and Commerce", Fifth Edition, ELBS, London, 1977.

Heckert J.B., "Controllership", Erlangga Edisi...., Jakarta.

Hartadi Bambang, "Sistem Pengendalian Intern (Dalam Hubungannya Dengan Manajemen dan Audit) BPFE, Edisi, Yogyakarta.

Heckert J.B, Wilson, James, "Controllership" $2^{\text {nd }}$ Ed, New York, The Ronald Press Company, 1963.

Imron Ali, "Pengendalian Intern", Armico, Bandung.

Longkutoy, John J, "Pengenalan Komputer", Mutiara Sumber Widya, Jakarta.
Majalah Akuntansi, IAI, Jakarta, Oktober 1991

Mulyadi, "Sistem Akuntansi", STIE YKPN, Yogyakarta.

Neuner, "Accounting Systems Installation Method and Procedure", Fifth Edition, Scranton, Pennsylvania, 1972.

Porter W. Thomas and Perry Williams., EDP Pengendalian dan Auditing", Erlangga, Edisi, Jakarta.

Steer M. Richard, "Efektifitas Organisasi", Erlangga, Jakarta.

Standar Pemeriksaan Akuntan Publik (SPAP), IAI, Jakarta, 1994.

Tuanakota Theoderus M, "Auditing", LPFE UI, Jakarta. 